\title{
Analysis of Intra-Industry Trade Between China, Japan, and Korea
}

\author{
Chang Yuan, ${ }^{1, *}$ and Yu-lan Du ${ }^{2}$ \\ ${ }^{1}$ School of Economics and Management, Nanjing University of Science and Technology, Nanjing, Jiangsu 210094, \\ China \\ ${ }^{2}$ School of Economics and Management, Nanjing University of Science and Technology, Nanjing, Jiangsu 210094, \\ China \\ *Corresponding author.Email: yuanc93@njust.edu.cn
}

\begin{abstract}
With the continuous development of China's economy, the scale of trade between China and Japan and between China and South Korea has developed rapidly in recent years. Since the 1990s, the trade between China and Japan and between China and South Korea has been dominated by manufacturing products, reflecting the characteristics of intra-industry trade. Meanwhile the changes of the trade structure have also reflected the transformation of China's industrial structure and the improvement of China's technology. Therefore, the analysis of the intra-industry trade between China and Japan and between China and South Korea has certain practical significance. At the same time, by studying the intra-industry trade between Japan and South Korea which are developed economies, it also has a certain degree of reference for China. This article mainly measures the intra-industry trade level and intra-industry trade structure among three countries through the G-L index and the GHM index, which are widely used when international scholars analyze intraindustry trade.
\end{abstract}

Keywords: intra-industry trade, G-L index, GHM index, manufactured goods

\section{INTRODUCTION}

China, Japan, and South Korea are geographically close. As the three largest economies in East Asia, with the development of regional economic integration, the scale of trade among the three countries has continued to expand in recent years. With the improvement of China's technology, the gap between China and the other two developed countries has been narrowing. And China has drawn on the experience of Japan and South Korea in formulating its development strategy. China's economic scale has been expanding since the reform and opening up, and China has now become Japan and South Korea's largest trading partners. At the same time South Korea and Japan have been the second and third partners in China's bilateral trade after the United States for a long time. In addition to the continuous expansion of trade scale, according to scholars' calculation, the proportion of intra-industry trade in ChinaJapan trade and China-Korea trade has risen sharply, which also makes the study of intra-industry trade between China and Japan and between China and South Korea more important.

\section{LITERATURE REVIEW}

\subsection{Studies of Foreign Scholars}

It is generally believed that the concept of intra-industry trade was first proposed by Verdoorn [1]. When he studied the impact of Belgium-Netherlands-Luxembourg Economic Union on international trade, he found that international trade within the same product group has increased significantly compared to when no economic union was established. Grubel and Llord introduced the classification, measurement, and causes of intra-industry trade in his book Intra-Industry Trade: The Theory and Measurement of International Trade in Differentiated Products [2]. Krugman further developed the theory of intra-industry trade, and proposed the theory of horizontal intra-industry trade and vertical intra-industry trade [3]. Lancaster deduced that even two very similar economies would have large-scale intra-industry trade under the assumption of a completely monopolistic competitive market, even if the two countries would not have trade exchanges based on the theory of comparative advantage [4]. Greenaway, Hine, and Minler proposed the GHM index to measure the structure of intra-industry trade using the price of imported and exported goods per unit to divide intra-industry trade into horizontal intra-industry trade and vertical intra-industry trade [5]. Japanese scholars Kyoji 
Fukao, Hikari Ishido, and Keiko Ito studied the changes in the East Asian trade model at that time and they found that although the development of intra-industry trade in East Asia was not as significant as that in the EU in the early 2000s, intra-industry trade, especially vertical intraindustry trade, has developed rapidly in the region. Through their empirical analysis, it was concluded that FDI had played a significant role in the development of intra-industry trade in East Asia [6].

\subsection{Studies of Domestic Scholars}

Because intra-industry trade emerged among developed countries after World War II, the research in this area started late in developing countries, and the overall level of intra-industry trade is backward. In recent years, with the development of China's economy and the progress of economic globalization, China's role in the development of the world economy is changing. The proportion of intraindustry trade in international trade is constantly expanding, and the number of researches on intra-industry trade has gradually increased.

Zhu Gangti and Jia Jifeng were the earliest scholars to study intra-industry trade in China. They introduced the theory of intra-industry trade in detail and thought that this theory was incomplete and could not replace the theory of comparative advantage [7]. Lu Minghong used the G-L index to measure the development of China's intra-industry trade at that time, however, because China's international trade data records were incomplete at that time, the results were biased [8]. Shi Zhiyu calculated the G-L index of intra-industry trade in East Asian countries, and pointed out that the increase in FDI and the growth of GDP per capita were the main reasons for promoting the development of intra-industry trade in East Asia [9]. Zhao Fang and Li Ji measured the intra-industry trade between China and Japan and the intra-industry trade between China and South Korea, and conducted an empirical analysis on the influencing factors of intra-industry trade between China and Japan and between China and South Korea. They found that both market size and FDI had a positive impact on intra-industry trade $[10,11]$.

\section{CONCEPTS AND INDEXEX OF INTRA- INDUSTRY TRADE}

\subsection{Basic concepts}

Intra-industry trade means that products of the same industry appear in both the import and export of a country in the same period. There are different international standards for the classification of industries. The fourth edition of the SITC is now commonly used. It is generally considered that the first three digits of the SITC are the same as the classification criteria for the same industry. The concept of intra-industry trade is proposed relative to inter-industry trade. Before World War II, due to the different endowments, generally speaking, in international trade, developed countries exported capital-intensive or technology-intensive products and imported laborintensive products, while developing countries did exactly the opposite. After World War II, some scholars found that trade between similar products in developed countries accounted for most of the international trade. According to different ratios of unit import prices and unit export prices of products in the same sector, intra-industry trade can be further divided into horizontal intra-industry trade and vertical intra-industry trade. Horizontal intra-industry trade means that within the same industry, the products imported and exported by a country have horizontal differences, that is, there is not much difference in technology, quality, and price, but only differences in appearance or function. Vertical intra-industry trade refers to the differences in technology, quality, and prices of products imported and exported by a country within the same industry. In general, horizontal intra-industry trade occurs in countries with similar levels of economic development and similar factor endowments, and vertical intra-industry trade occurs between countries with large differences in economic development levels and large differences in factor endowments.

\subsection{G-L Index}

At present, the commonly used method for measuring the development level of intra-industry trade is the G-L index proposed by Grubel and Lloyd in 1975. The calculation formula is

$$
G L_{i}=1-\frac{\left|X_{i}-M_{i}\right|}{X_{i}+M_{i}}
$$

In the above formula, $\mathrm{Xi}$ and $\mathrm{Mi}$ respectively represent the export trade value and import trade value of a country in industry i. $G L_{i}$ is the intra-industry trade index of industry i. When $X_{i}$ or $M_{i}$ is $0, G L_{i}$ is 0 , then at industry i, the country only imports or exports, industry $\mathrm{i}$ is a complete interindustry trade; when $X_{i}$ and $M_{i}$ are equal, $G L_{i}$ is 1 , then industry $\mathrm{i}$ is a complete intra-industry trade. Taking the proportion of the total import and export of each industry to the total import and export of the country as a weight, sum the G-L indexes of all industries to get the country's intra-industry trade index. The calculation formula is

$$
G L=\frac{\sum G L_{i} *\left(X_{i}+M_{i}\right)}{\sum\left(X_{i}+M_{i}\right)}
$$

At the same time, Grubel and Lloyd thought that the above formula can reflect the level of intra-industry trade in an industry when its import and export is balanced. If there is an imbalance in import and export, a revised index is needed to measure the overall level of intra-industry trade development in a country. The formula for calculating the revised index is

$$
\overline{G L}=\frac{\sum\left(X_{i}+M_{i}\right)-\sum\left|X_{i}-M_{i}\right|}{\sum\left(X_{i}+M_{i}\right)-\left|\sum X_{i}-\sum M_{i}\right|}
$$

Therefore, formula 3 is often used when calculating the level of intra-industry trade of a specific industry, while 
industry trade of a country as a whole.

\subsection{Calculation and analysis of $G-L$ index}

According to the formula of G-L index, the intra-industry trade levels between China and Japan, between China and South Korea, and between Japan and South Korea from 2009 to 2018 is measured. The calculation range is nine industries from SITC0 to SITC8. Because the SITC9 industry is mainly unspecified classification of products, so this article does not calculate the G-L index of the SITC9 industry. Due to errors in the statistics of the trade data of the two countries by the United Nations Trade Database, the data used in this article are China as the reporter, Japan and South Korea as partners when calculating the G-L index of China, and the data used in the calculation of the Japan-Korea intra-industry trade index are Japan as the reporter and South Korea as the partner. The G-L index measurement results are shown in the following table.

\section{DATA ANALYSIS}

Table 1 The G-L index of intra-industry trade between China and Japan

\begin{tabular}{|c|c|c|c|c|c|c|c|c|c|}
\hline & S0 & S1 & S2 & S3 & S4 & S5 & S6 & S7 & S8 \\
\hline 2009 & 0.096 & 0.307 & 0.052 & 0.241 & 0.237 & 0.355 & 0.343 & 0.450 & 0.217 \\
\hline 2010 & 0.109 & 0.415 & 0.070 & 0.313 & 0.371 & 0.368 & 0.380 & 0.404 & 0.248 \\
\hline 2011 & 0.049 & 0.323 & 0.072 & 0.267 & 0.356 & 0.391 & 0.400 & 0.386 & 0.247 \\
\hline 2012 & 0.051 & 0.510 & 0.064 & 0.223 & 0.222 & 0.393 & 0.416 & 0.434 & 0.259 \\
\hline 2013 & 0.059 & 0.425 & 0.070 & 0.307 & 0.123 & 0.376 & 0.428 & 0.472 & 0.232 \\
\hline 2014 & 0.070 & 0.523 & 0.085 & 0.337 & 0.212 & 0.387 & 0.454 & 0.504 & 0.246 \\
\hline 2015 & 0.089 & 0.398 & 0.099 & 0.233 & 0.131 & 0.388 & 0.457 & 0.522 & 0.255 \\
\hline 2016 & 0.104 & 0.454 & 0.119 & 0.159 & 0.202 & 0.394 & 0.463 & 0.491 & 0.251 \\
\hline 2017 & 0.100 & 0.515 & 0.117 & 0.241 & 0.213 & 0.388 & 0.466 & 0.461 & 0.249 \\
\hline 2018 & 0.144 & 0.496 & 0.109 & 0.377 & 0.325 & 0.367 & 0.471 & 0.440 & 0.254 \\
\hline
\end{tabular}

Table 2 The G-L index of intra-industry trade between China and Korea

\begin{tabular}{|c|c|c|c|c|c|c|c|c|c|}
\hline & S0 & S1 & S2 & S3 & S4 & S5 & S6 & S7 & S8 \\
\hline 2009 & 0.185 & 0.337 & 0.120 & 0.111 & 0.237 & 0.263 & 0.562 & 0.452 & 0.227 \\
\hline 2010 & 0.177 & 0.342 & 0.117 & 0.129 & 0.209 & 0.297 & 0.557 & 0.412 & 0.237 \\
\hline 2011 & 0.210 & 0.490 & 0.153 & 0.150 & 0.450 & 0.321 & 0.527 & 0.441 & 0.284 \\
\hline 2012 & 0.195 & 0.533 & 0.129 & 0.206 & 0.235 & 0.282 & 0.549 & 0.468 & 0.286 \\
\hline 2013 & 0.224 & 0.580 & 0.135 & 0.233 & 0.219 & 0.275 & 0.512 & 0.487 & 0.282 \\
\hline 2014 & 0.221 & 0.758 & 0.125 & 0.286 & 0.258 & 0.311 & 0.425 & 0.478 & 0.275 \\
\hline 2015 & 0.252 & 0.679 & 0.130 & 0.335 & 0.298 & 0.333 & 0.549 & 0.489 & 0.282 \\
\hline 2016 & 0.286 & 0.841 & 0.133 & 0.232 & 0.142 & 0.340 & 0.568 & 0.481 & 0.285 \\
\hline 2017 & 0.247 & 0.812 & 0.172 & 0.308 & 0.105 & 0.376 & 0.562 & 0.458 & 0.303 \\
\hline 2018 & 0.240 & 0.743 & 0.136 & 0.254 & 0.146 & 0.380 & 0.532 & 0.426 & 0.310 \\
\hline
\end{tabular}


Table 3 The G-L index of intra-industry trade between Japan and Korea

\begin{tabular}{|c|c|c|c|c|c|c|c|c|c|}
\hline & S0 & S1 & S2 & S3 & S4 & S5 & S6 & S7 & S8 \\
\hline 2009 & 0.426 & 0.297 & 0.339 & 0.495 & 0.174 & 0.327 & 0.424 & 0.560 & 0.400 \\
\hline 2010 & 0.396 & 0.243 & 0.402 & 0.400 & 0.171 & 0.325 & 0.456 & 0.468 & 0.382 \\
\hline 2011 & 0.314 & 0.243 & 0.426 & 0.337 & 0.200 & 0.374 & 0.553 & 0.465 & 0.340 \\
\hline 2012 & 0.254 & 0.234 & 0.325 & 0.325 & 0.304 & 0.404 & 0.572 & 0.526 & 0.290 \\
\hline 2013 & 0.245 & 0.239 & 0.274 & 0.423 & 0.219 & 0.394 & 0.566 & 0.523 & 0.272 \\
\hline 2014 & 0.255 & 0.189 & 0.345 & 0.440 & 0.227 & 0.427 & 0.603 & 0.552 & 0.286 \\
\hline 2015 & 0.340 & 0.199 & 0.390 & 0.404 & 0.290 & 0.444 & 0.598 & 0.584 & 0.298 \\
\hline 2016 & 0.372 & 0.218 & 0.379 & 0.586 & 0.409 & 0.501 & 0.623 & 0.551 & 0.309 \\
\hline 2017 & 0.382 & 0.212 & 0.324 & 0.525 & 0.659 & 0.511 & 0.652 & 0.491 & 0.311 \\
\hline 2018 & 0.427 & 0.203 & 0.301 & 0.497 & 0.692 & 0.568 & 0.644 & 0.540 & 0.290 \\
\hline
\end{tabular}

When calculating the G-L index of intra-industry trade, some scholars directly use the overall of import and export volume of sections in SITC to calculate. Personally, this calculation method violates the principle that the first three digits of SITC are the same as the industry classification. So, this article still uses the proportion of trade volumes of different groups of the same sector as the weight, and the G-L index of each group of products is added up. As a result, the calculation results in the above table are smaller than those of previous scholars to a certain degree.

It can be seen from the calculation results of the G-L index that the development level of intra-industry trade among the three East Asian countries is not as high as EU. The reason for this phenomenon may be that on the one hand, the development levels of the industries among the three countries are different. The basis of intra-industry trade development is not as good as that of the economies in the EU. On the other hand, due to the different characteristics of the three countries, factor endowments and comparative advantages of the three countries are dissimilar.

\subsection{Calculation and analysis of GHM index}

This article selected the top 10 industries with the highest trade volume among all industries and calculated the GHM index of these industries. The following table is the intraindustry trade structure index of these industries. Due to the lack of some industries trade data, the GHM index of these industries is replaced by '-' in the table.

Table 4 The GHM index of intra-industry trade between China and Japan

\begin{tabular}{|c|c|c|c|c|c|c|c|c|c|c|}
\hline & 776 & 764 & 728 & 778 & 784 & 772 & 781 & 752 & 874 & 511 \\
\hline 2009 & - & - & 0.179 & - & 0.466 & - & 0.963 & - & 0.330 & 3.649 \\
\hline 2010 & - & - & 0.211 & - & - & 0.369 & 0.923 & - & - & 3.763 \\
\hline 2011 & - & - & - & - & - & 0.330 & 0.901 & - & 0.357 & 3.767 \\
\hline 2012 & - & - & - & - & - & 0.347 & - & - & - & 2.816 \\
\hline 2013 & - & - & - & - & 0.438 & 0.356 & 1.009 & - & - & 2.450 \\
\hline 2014 & 0.163 & - & - & - & 0.434 & - & 0.857 & - & - & 2.764 \\
\hline 2015 & 0.164 & - & - & - & 0.451 & - & 1.216 & - & 0.228 & 3.627 \\
\hline 2016 & - & - & - & - & 0.467 & - & 0.728 & - & - & 3.714 \\
\hline 2017 & 0.007 & 0.465 & 0.098 & 0.551 & 0.463 & 0.337 & 0.863 & 2.251 & 0.308 & 3.417 \\
\hline 2018 & - & - & - & - & - & - & 0.806 & - & - & 3.800 \\
\hline
\end{tabular}


Table 5 The GHM index of intra-industry trade between China and Korea

\begin{tabular}{|c|c|c|c|c|c|c|c|c|c|c|}
\hline & 776 & 764 & 871 & 511 & 728 & 752 & 334 & 772 & 778 & 759 \\
\hline 2009 & - & - & - & 1.179 & 0.269 & - & 1.025 & - & - & 0.033 \\
\hline 2010 & - & - & - & 1.262 & 0.240 & - & 0.907 & 0.541 & - & 0.040 \\
\hline 2011 & - & - & - & 1.375 & - & - & 0.883 & 0.507 & - & 0.037 \\
\hline 2012 & - & - & 0.518 & 1.347 & - & - & 0.866 & 0.452 & - & 0.055 \\
\hline 2013 & - & - & - & 1.107 & - & - & 0.865 & 0.507 & - & 0.042 \\
\hline 2014 & 1.021 & - & - & 1.327 & - & - & 0.938 & - & - & 0.038 \\
\hline 2015 & 0.981 & - & - & 2.049 & - & - & 0.919 & - & - & 0.054 \\
\hline 2016 & - & - & - & 2.524 & - & - & 0.916 & - & - & 0.056 \\
\hline 2017 & 0.028 & 0.579 & 0.400 & 2.067 & 0.152 & - & 0.896 & 0.470 & - & 0.052 \\
\hline 2018 & 0.025 & - & - & 2.208 & 0.129 & - & 0.916 & - & - & - \\
\hline
\end{tabular}

Table 6 The GHM index of intra-industry trade between Japan and Korea

\begin{tabular}{|c|c|c|c|c|c|c|c|c|c|c|}
\hline & 728 & 334 & 776 & 931 & 673 & 874 & 598 & 582 & 778 & 511 \\
\hline 2009 & 4.909 & 0.995 & - & - & 0.995 & 3.118 & 9.859 & 6.531 & - & 1.203 \\
\hline 2010 & 4.292 & 0.923 & - & - & 0.919 & 3.732 & 6.397 & 5.685 & - & 1.044 \\
\hline 2011 & - & 0.923 & - & - & 0.929 & 3.825 & 9.019 & 5.678 & - & 1.237 \\
\hline 2012 & - & 0.889 & - & - & 0.940 & 3.009 & 6.159 & 6.063 & - & 1.125 \\
\hline 2013 & 3.617 & 0.935 & - & - & 1.037 & 3.297 & 4.991 & 6.156 & - & 1.465 \\
\hline 2014 & - & 0.963 & - & - & 0.984 & 4.168 & 6.506 & 5.926 & 0.856 & 1.218 \\
\hline 2015 & 3.944 & 1.029 & - & - & 0.972 & 3.366 & 5.447 & 5.720 & 1.100 & 1.124 \\
\hline 2016 & - & 0.957 & - & - & 0.907 & 2.637 & 4.560 & 5.560 & 0.847 & 0.993 \\
\hline 2017 & 7.405 & 0.973 & - & - & 1.000 & 2.486 & 6.499 & 5.391 & - & 1.060 \\
\hline 2018 & 8.397 & 0.894 & 1.389 & - & 0.999 & 3.380 & 7.028 & 4.986 & 1.461 & 0.925 \\
\hline
\end{tabular}

From the Greenaway classification mentioned earlier, intra-industry trade can be divided into horizontal intraindustry trade, superior vertical intra-industry trade, and inferior vertical intra-industry trade. From the results in the table above, it can be seen that only 511 products in SinoJapanese intra-industry trade and Sino-Korean intraindustry trade is in an advantageous position, and most major trade industries are in a disadvantageous position. In Japanese-Korean trade, Japan is basically in an absolute superior position in the field of manufactured goods. This result also reflects Japan's leading position among the three largest economies in East Asia.

According to the SITC, SITC5 and SITC7 are mainly capital-intensive and technology-intensive products, and SITC6 and SITC8 are mainly labor-intensive products. The top eight products in terms of trade volume between China and Japan are all from SITC7. The products in this sector are mainly machinery and transportation equipment. The growth in trade between China and Japan mainly comes from this sector. Based on the objective reality of the differences in factor endowment between China and Japan, it can be inferred that in the Sino-Japanese trade division of labor, China mainly produces low-quality labor-intensive products, while Japan mainly produces high-quality capital-intensive or technology-intensive products. It also accords with the results calculated using the Greenaway classification method. The price of unit products exported by China is lower than the price of unit products imported.

\section{CONCLUSION AND POLICY RECOMMENDATION}

By measuring the G-L index and GHM index of intraindustry trade among China, Japan, and South Korea, it can be seen that the current level of intra-industry trade development among the three East Asian countries is not high, but with the continuous expansion of the scale of trade among the three countries, the level of trade development is also increasing. At present, it is mainly believed that the development of intra-industry trade is related to the differences in market size, demand structure, FDI and market openness of the two countries. It is foreseeable that with the process of economic integration in East Asia, in the future, the economic structure and industrial structure among the three major economies will 
[6]Kyoji Fukao, Hikari Ishido, Keiko Ito. 2003. Vertical intra-industry trade and foreign direct investment in East Asia. Journal of the Japanese and International Economies. Vol. 17(4)

[7]Zhu Gangti, Jia Jifeng. 1985. Commentary on the Theory of "Intra-industry Trade". Journal of International Trade, No.5.

[8]Lu Minghong. 1994.Measurement and Evaluation of China's Intra-industry Trade Index. Journal of International Trade, No.5.

[9]Shi Zhiyu. 2003.An Empirical Study on the Development Trend of Intra-industry Trades in East Asia-Proposals on the Development of Sino-East Asia Intra -industry Trades. Journal of Finance and Economics, Vol.29, No.9.

[10] Zhao Fang, Li Ji. 2010. An Empirical Analysis of the Intra-industry Trade between China and Korea. International Economics and Trade Research, Vol.26, No.3.

[11] Zhao Fang, Li Ji. 2010. Empirical Research on Sino-Japanese Bilateral Intra-industry Trade and Influencing Factors. World Economy Study, No.10.

\section{REFERENCES}

[1]Raymond Vernon. 1966. International Investment and International Trade in the Product Cycle. The Quarterly Journal of Economics, Vol. 80(2).

[2]Herb Grubel, Peter Lloyd. 1975. Intra-industry trade: the theory and measurement of international trade in differentiated products.

[3]Paul R. Krugman. 1979. Increasing returns, monopolistic competition, and international trade. Journal of International Economics, Vol. 9(4).

[4]Kelvin Lancaster. 1980. Intra-industry trade under perfect monopolistic competition. Journal of International Economics, Vol. 10(2).

[5]David Greenaway, Robert Hine, Chris Milner. 1994. Country-specific factors and the pattern of horizontal and vertical intra-industry trade in the UK. Review of World Economics. Vol. 130(1). 